\title{
Optimized threshold for serum HCV RNA to predict treatment outcomes in hepatitis $C$ patients receiving peginterferon alfa-2a/ribavirin
}

\author{
S. Zeuzem, ${ }^{1}$ M. Rodríguez-Torres, ${ }^{2}$ K. Rajender Reddy, ${ }^{3}$ P. Marcellin, ${ }^{4}$ M. Diago, ${ }^{5}$ A. Craxi, ${ }^{6}$ \\ P. Pockros, ${ }^{7}$ M. Rizzetto, ${ }^{8}$ D. Bernstein, ${ }^{9}$ M. L. Shiffman, ${ }^{10}$ A. Lin, ${ }^{11}$ F. Tatsch $^{12}$ and \\ S. Hadziyannis ${ }^{13}{ }_{1}^{1}$ Johann Wolfgang Goethe University Medical Center, Frankfurt am Main, Germany; ${ }^{2}$ Fundación de Investigación De Diego, \\ Santurce, PR, USA; ${ }^{3}$ Gastroenterology and Hepatology, University of Pennsylvania, Philadelphia, PA, USA; ${ }^{4}$ University of Paris, Clichy, France; \\ ${ }^{5}$ Hospital de Valencia, Valencia, Spain; ${ }^{6}$ Gastroenterology and Hepatology, University of Palermo, Palermo, Italy; ${ }^{7}$ Scripps Clinic, La Jolla, CA, USA; \\ ${ }^{8}$ Gastroenterology and Hepatology, San Giovanni Battista Hospital, Turin, Italy; ${ }^{9}$ Digestive Diseases Institute of the Division of Gastroenterology, \\ Hepatology, and Nutrition, Manhasset, NY, USA; ${ }^{10}$ Liver Institute of Virginia, Bon Secours Health System, Newport News, VA, USA; ${ }^{11}$ Roche, Nutley, \\ NJ, USA; ${ }^{12}$ Roche, Basel, Switzerland; and ${ }^{13}$ Department of Medicine and Hepatology, Henry Dunant Hospital, Athens, Greece
}

Received December 2011; accepted for publication February 2012

SUMMARY. It is unclear whether the current threshold for 'high' hepatitis C virus (HCV) RNA level (800 $000 \mathrm{IU} / \mathrm{mL})$ is optimal for predicting sustained virological response (SVR). We retrospectively analysed pretreatment HCV RNA levels and SVR rates in 1529 mono-infected and 176 HIV-HCV co-infected patients treated with peginterferon alfa-2a (40 kD) plus ribavirin. We improved the threshold for differentiating low and high viral load by fitting semiparametric generalized additive logistic regression models to the data and constructing receiver operating characteristics curves. Among HCV genotype 1 mono-infected patients, the difference in SVR rates between those with low and high baseline HCV RNA levels was $27 \%$ (70\% vs $43 \%$ ) when $400000 \mathrm{IU} / \mathrm{mL}$ was used and
$16 \%$ (59\% vs 43\%) when $800000 \mathrm{IU} / \mathrm{mL}$ was used. In HIVHCV genotype 1 co-infected patients, the difference was $51 \%$ ( $71 \%$ vs $20 \%$ ) when $400000 \mathrm{IU} / \mathrm{mL}$ was used and $43 \%$ (61\% vs $18 \%$ ) when $800000 \mathrm{IU} / \mathrm{mL}$ was used. A lower threshold (200 $000 \mathrm{IU} / \mathrm{mL}$ ) was identified for genotype 1 mono-infected patients with 'normal' alanine aminotransferase (ALT) levels. No threshold could be identified in HCV genotype 2 or 3 patients. A threshold HCV RNA level of $400000 \mathrm{IU} / \mathrm{mL}$ is optimal for differentiating high and low probability of SVR in genotype 1-infected individuals with elevated ALT.

Keywords: alanine aminotransferase, baseline predictor, HCV genotype 1 , HCV viral load, sustained virological response.
Hepatitis C virus (HCV) genotype and pretreatment $\mathrm{HCV}$ RNA level are important determinants of the outcome of treatment with pegylated interferon plus ribavirin [1,2]. Infection with HCV genotype 1 and the presence of a 'high' baseline HCV RNA level portends a lower probability of sustained virological response (SVR) [1-3]. A 'high'

Abbreviations: ALT, alanine aminotransferase; CI, confidence interval; FPF, false-positive fraction; GAM, generalized additive logistic regression model; $\mathrm{HCV}$, hepatitis $\mathrm{C}$ virus; IU, international units; MLR, multiple logistic regression; OR, odds ratio; PCR, polymerase chain reaction; ROC, receiver operating characteristics curve; RVR, rapid virological response; SVR, sustained virological response; TPF, true-positive fraction.

Correspondence: Stefan Zeuzem, MD, Department of Internal Medicine, J.W. Goethe University Hospital, Theodor-Stern-Kai 7, 60590 Frankfurt, Germany.

E-mail: zeuzem@em.uni-frankfurt.de
HCV RNA level was originally defined as $>2 \times 10^{6}$ copies/ $\mathrm{mL}$ [4] on the basis of the results of phase 3 studies of conventional interferon alfa-2b plus ribavirin [5,6]. This definition was utilized in phase 3 registration trials of peginterferon alfa-2a in monotherapy [7-9] and in combination with ribavirin [10-12]. Serum HCV RNA levels have since been standardized and reported in International Units (IU) [13]. Despite this, the cut-off between high and low viral load has not been modified, and the current licences for these products continue to reflect the older data.

The time required to become HCV RNA undetectable after initiating treatment impacts the rate of SVR, and this information can be utilized to adjust treatment duration. Patients with HCV genotype 1, a rapid virological response (RVR) and low viral load have similar rates of SVR whether treated for 24 or 48 weeks [2]. Consequently in the EU, 24 or 48 weeks of treatment with peginterferon alfa-2a plus ribavirin is recommended for HCV genotype 1 and 4 patients 
with a 'low' baseline viral load and RVR [14]. In this recommendation, the definition utilized for low viral load was $<600000$ or $<800000 \mathrm{IU} / \mathrm{mL}$. Furthermore, an abbreviated 16-week regimen of peginterferon alfa-2a plus ribavirin has been licensed in the EU for patients infected with HCV genotypes 2 or 3 with a low HCV RNA level [14]. Similar recommendations have been suggested for patients with HIV and HCV co-infection and genotypes 2 and 3 [15].

Patients achieving an RVR with a high pretreatment serum HCV RNA level have a lower probability of achieving an SVR than those with a low level when treated with abbreviated regimens [16-19]. Thus, in the era of responseguided therapy, a precise definition of what constitutes a low and high HCV RNA level is needed.

We analysed pretreatment HCV RNA levels and SVR rates in patients treated with the combination of peginterferon alfa-2a $(40 \mathrm{kD})$ plus ribavirin in several randomized international phase 3 trials.

\section{METHODS}

This retrospective analysis included data from randomized, phase 3 trials of peginterferon alfa-2a $(40 \mathrm{kD})$ plus ribavirin [10,11,19-21]. Four trials recruited HCV mono-infected patients; in three of these studies, patients had elevated serum alanine aminotransferase (ALT) levels at baseline [10,11,19], one of which was restricted to patients with HCV genotype 2 or 3 infection [19]. Only noncirrhotic patients with persistently normal ALT levels were eligible for the fourth study [20]. We also analysed data from the APRICOT trial, which enrolled patients with HIV-HCV co-infection [21].

The HCV mono-infected patients with elevated ALT levels included in this analysis were treated with peginterferon alfa-2a $(40 \mathrm{kD}) 180 \mu \mathrm{g}$ per week plus ribavirin 1000/ $1200 \mathrm{mg}$ per day for 48 weeks (HCV genotype 1 infection) or peginterferon alfa-2a $(40 \mathrm{kD}) 180 \mu \mathrm{g}$ per week plus ribavirin $800 \mathrm{mg}$ per day for 24 weeks (HCV genotype 2 or 3 infection). The genotype 1 -infected patients with persistently normal ALT levels and the genotype 1-infected patients with HIV-HCV co-infection included in this analysis were treated with peginterferon alfa-2a (40 kD) $180 \mu \mathrm{g}$ per week plus ribavirin $800 \mathrm{mg}$ per day for 48 weeks.

\section{Measurement of serum HCV RNA levels}

Serum HCV RNA levels were quantified with the COBAS AMPLICOR HCV MONITOR Test, v2.0 (limit of quantitation 600 IU/mL; Roche, Rotkreuz, Switzerland). Samples were analysed using the COBAS AMPLICOR HCV Test, v2.0, limit of detection $50 \mathrm{IU} / \mathrm{mL}$ (Roche, Pleasanton, CA, USA).

\section{Primary efficacy outcome}

The primary efficacy endpoint in each trial was SVR, defined as undetectable HCV RNA by the qualitative PCR assay
$(<50 \mathrm{IU} / \mathrm{mL})$ at the end of a 24 -week untreated follow-up period.

\section{Data analysis}

The association between pretreatment serum HCV RNA level and SVR was examined by multiple logistic regression (MLR) analysis. Factors considered for inclusion in the MLR models were pretreatment serum HCV RNA level $\left(\log _{10} \mathrm{IU} / \mathrm{mL}\right)$, age, body weight and ALT quotient, gender (male vs female), histological diagnosis (cirrhosis/ transition to cirrhosis vs no cirrhosis/transition to fibrosis) and race.

To evaluate the possibility of nonlinear associations between continuous explanatory factors and SVR, a semiparametric generalized additive logistic regression model (GAM) was fitted to the data [22]. For ease of interpretation, and to visualize the relationship between SVR and viral load, the probability of SVR was plotted as a function of $\log _{10}$ pretreatment HCV RNA values using univariate GAM curves. Receiver operating characteristics (ROC) curves of pretreatment serum HCV RNA level were plotted for the prediction of SVR. These show the true-positive fraction $(\mathrm{TPF}=$ sensitivity $)$ and corresponding false-positive fraction (FPF $=1$-specificity) for each of the observed HCV RNA values used as a cut-off to predict SVR.

SAS version 8.2 software and S-PLUS were used in all statistical analyses.

\section{RESULTS}

Data from 1529 patients with HCV mono-infection, including 140 with persistently normal serum ALT, and 176 patients with $\mathrm{HIV}-\mathrm{HCV}$ co-infection, were included in the analysis. The baseline characteristics of these individuals are presented in Table 1.

\section{Patients with HCV mono-infection}

HCV genotype 1, elevated serum ALT levels

Baseline factors predictive of SVR in the MLR analysis of data from HCV mono-infected genotype 1 patients with elevated serum ALT levels included lower pretreatment HCV RNA level $(P<0.0001)$, higher ALT quotient $(P<0.0001)$, lower body weight $(P=0.0003)$, younger age $(P=0.0012)$ and absence of advanced liver fibrosis $(P=0.0356)$ (Table 2). Analysis of the linearity of the logit for SVR indicated a nonlinear effect of pretreatment HCV RNA level and age.

The semiparametric GAM analysis showed a decrease in SVR with increasing HCV RNA values in the range from $\sim 4 \log _{10}$ to $6 \log _{10} \mathrm{IU} / \mathrm{mL}$. For example, in a patient with a pretreatment HCV RNA level of $\sim 5.6 \quad \log _{10} \mathrm{IU} / \mathrm{mL}$ ( $\sim 400000 \mathrm{IU} / \mathrm{mL}$ ) (and any set of disease characteristics), the probability of an SVR was identical to that for a patient 
Table 1 Baseline characteristics of patients included in the analysis

\begin{tabular}{|c|c|c|c|c|c|}
\hline \multirow[b]{3}{*}{ Characteristic } & \multicolumn{4}{|c|}{ HCV mono-infection $(n=1529)$} & \multirow{3}{*}{$\begin{array}{l}\text { HIV-HCV genotype } \\
1 \text { co-infection } \\
(n=176)\end{array}$} \\
\hline & \multicolumn{3}{|c|}{ Elevated ALT levels $(n=1389)$} & \multirow{2}{*}{$\begin{array}{l}\text { Persistently 'normal' } \\
\text { ALT levels } \\
\text { Genotype } 1 \\
(n=140)\end{array}$} & \\
\hline & $\begin{array}{c}\text { Genotype } 1 \\
(n=568)\end{array}$ & $\begin{array}{c}\text { Genotype } 2 \\
(n=395)\end{array}$ & $\begin{array}{c}\text { Genotype } 3 \\
(n=426)\end{array}$ & & \\
\hline Male, $n(\%)$ & $388(68.3)$ & $238(60.3)$ & $283(66.4)$ & $54(38.6)$ & $146(83)$ \\
\hline Age*, years & $43.8 \pm 10.4$ & $48.7 \pm 9.5$ & $41.5 \pm 9.4$ & $44.1 \pm 9.6$ & $39.8 \pm 7.9$ \\
\hline Weight*, kg & $79.6 \pm 16.9$ & $83.6 \pm 19.1$ & $79.0 \pm 17.1$ & $75.1 \pm 17.6$ & $73.0 \pm 14.1$ \\
\hline $\mathrm{BMI}^{*}, \mathrm{~kg} / \mathrm{m}^{2}$ & $26.9 \pm 4.9$ & $28.4 \pm 5.8$ & $26.5 \pm 5.0$ & $26.6 \pm 5.3$ & $24.5 \pm 4.4$ \\
\hline \multicolumn{6}{|l|}{ Race, $n(\%)$} \\
\hline Caucasian & $485(85.4)$ & $336(85.1)$ & $386(90.6)$ & $120(85.7)$ & $137(77.8)$ \\
\hline Non-Caucasian & $83(14.6)$ & $59(14.9)$ & $40(9.4)$ & $20(14.3)$ & $39(22)$ \\
\hline \multicolumn{6}{|l|}{ Histological diagnosis, $n(\%)$} \\
\hline No cirrhosis & $452(79.6)$ & $298(75.4)$ & $338(79.3)$ & $139(99.3)$ & $152(86.4)$ \\
\hline Bridging fibrosis/cirrhosis & $116(20.4)$ & $97(24.6)$ & $88(20.7)$ & 0 & $24(13.6)$ \\
\hline Unknown & 0 & 0 & 0 & $1(0.7)$ & 0 \\
\hline
\end{tabular}

ALT, alanine aminotransferase. *Values are mean \pm standard deviation.

Table 2 Multiple logistic regression analysis of explanatory factors for SVR in HCV genotype 1 patients

\begin{tabular}{|c|c|c|c|}
\hline \multirow[b]{3}{*}{ Factor } & \multicolumn{2}{|l|}{ HCV mono-infection } & \multirow{3}{*}{$\begin{array}{l}\text { HIV-HCV co-infection } \\
\text { Elevated ALT levels } \\
(n=176) \\
\begin{array}{l}\text { Odds ratio }(95 \% \mathrm{CI}) ; \\
P \text {-value }\end{array}\end{array}$} \\
\hline & $\begin{array}{l}\text { Elevated ALT levels } \\
(n=568)\end{array}$ & $\begin{array}{l}\text { 'Normal' ALT levels } \\
(n=138)\end{array}$ & \\
\hline & Odds ratio $(95 \% \mathrm{CI}) ; P$-value & Odds ratio $(95 \% \mathrm{CI}) ; P$-value & \\
\hline $\begin{array}{l}\text { HCV RNA per } \\
1-\log _{10} \mathrm{IU} / \mathrm{mL} \\
\text { increment }\end{array}$ & $\begin{array}{l}0.524(0.388-0.708) \\
P<0.0001\end{array}$ & $\begin{array}{l}0.362(0.160-0.822) \\
P=0.0152\end{array}$ & $\begin{array}{l}0.312(0.186-0.523) ; \\
\quad P<0.0001\end{array}$ \\
\hline $\begin{array}{l}\text { ALT ratio per } \\
\text { 1-unit decrement }\end{array}$ & $\begin{array}{l}0.821(0.744-0.906) \\
\quad P<0.0001\end{array}$ & $\begin{array}{l}0.505(0.045-5.619) \\
P=0.5780\end{array}$ & $\begin{array}{l}0.741(0.566-0.969) ; \\
P=0.0284\end{array}$ \\
\hline $\begin{array}{l}\text { Body weight per } \\
\text { 10-kg increment }\end{array}$ & $\begin{array}{l}0.802(0.712-0.904) \\
P=0.0003\end{array}$ & $\begin{array}{l}0.808(0.637-1.024) \\
P=0.0778\end{array}$ & $\begin{array}{l}0.830(0.589-1.168) ; \\
P=0.2851\end{array}$ \\
\hline $\begin{array}{l}\text { Age per 10-year } \\
\text { increment }\end{array}$ & $\begin{array}{l}0.737(0.613 \text { to }-0.887) \\
P=0.0012\end{array}$ & $\begin{array}{l}0.806(0.542-1.196) \\
P=0.2841\end{array}$ & $\begin{array}{l}0.710(0.415-1.215) ; \\
P=0.2116\end{array}$ \\
\hline $\begin{array}{l}\text { Bridging fibrosis/ } \\
\text { cirrhosis (yes vs no) }\end{array}$ & $\begin{array}{l}0.604(0.378-0.967) \\
P=0.0356\end{array}$ & NA & $\begin{array}{l}0.370(0.103-1.327) ; \\
P=0.1271\end{array}$ \\
\hline $\begin{array}{l}\text { Race (non-Caucasian vs } \\
\text { Caucasian) }\end{array}$ & $\begin{array}{l}0.697(0.418-1.162) \\
P=0.1665\end{array}$ & $\begin{array}{l}0.350(0.102-1.196) \\
P=0.0939\end{array}$ & $\begin{array}{l}0.963(0.344-2.696) ; \\
P=0.9431\end{array}$ \\
\hline Gender (male vs female) & $\begin{array}{l}0.887(0.585-1.347) \\
P=0.5746\end{array}$ & $\begin{array}{l}0.756(0.320-1.785) \\
P=0.5236\end{array}$ & $\begin{array}{l}0.608(0.214-1.731) ; \\
P=0.3516\end{array}$ \\
\hline
\end{tabular}

ALT, alanine aminotransferase; SVR, sustained virological response.

with the same set of disease characteristics when HCV RNA levels in the model were ignored. Similarly, a univariate GAM analysis with pretreatment HCV RNA level as the exploratory variable showed that the probability of an SVR at an HCV RNA level of $400000 \mathrm{IU} / \mathrm{mL}$ was 0.5 , which is close to the crude SVR rate (Fig. 1a). For HCV
RNA values above $400000 \mathrm{IU} / \mathrm{mL}$, the curve of predicted SVR probabilities is flat, and the decrease in SVR rate is moderate.

These findings are consistent with the observed SVR rates shown in Fig. 2a. Among patients with a pretreatment HCV RNA level $\leq 400000 \mathrm{IU} / \mathrm{mL}$, the SVR rate was $70 \%$ (91/ 

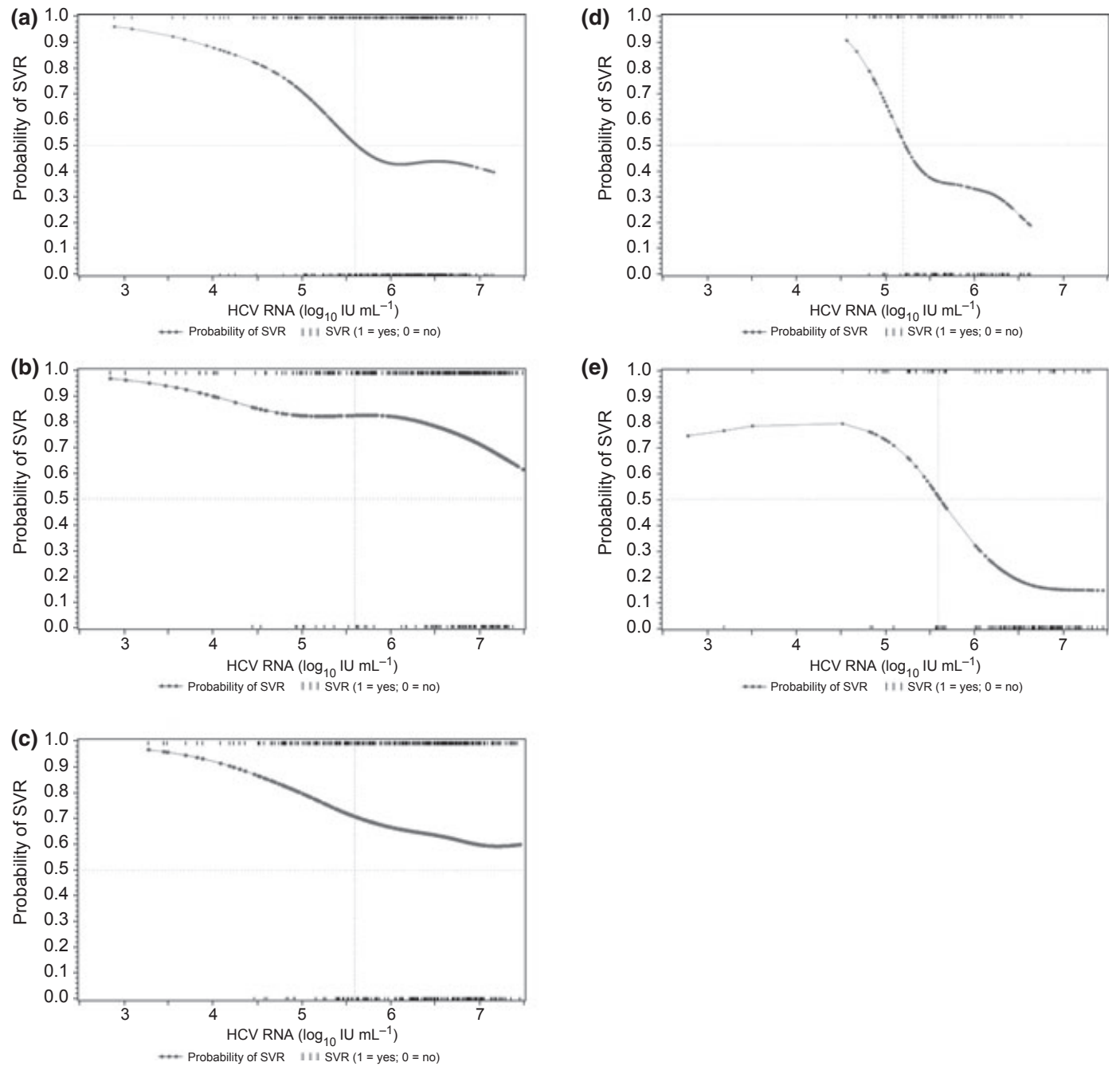

Fig. 1 Generalized additive logistic regression model plotting the effect of hepatitis C virus (HCV) RNA (log 10 IU/mL) on the probability of achieving a sustained virological response (SVR). Higher values on the vertical scale correspond to a higher probability of predicting an SVR, while a value of 0.5 corresponds to no contribution towards predicting SVR. (A) HCV genotype 1-infected patients with elevated alanine aminotransferase (ALT) levels; (B) HCV genotype 2-infected patients with elevated ALT levels; (C) HCV genotype 3-infected patients with elevated ALT levels; (D) HCV genotype 1-infected patients with persistently 'normal' serum ALT levels; (E) HCV genotype 1-infected patients co-infected with HIV.

130). The SVR rate was considerably lower among patients with an HCV RNA level $>400000$ IU/mL (43\%; 188/438). Thus, when $400000 \mathrm{IU} / \mathrm{mL}$ was selected as the cut-off, the difference in SVR rate was $27 \%$. By contrast, when using the conventional cut-off of $800000 \mathrm{IU} / \mathrm{mL}$, the difference in SVR rate decreased to $16 \%$ (Fig. 2a). Interestingly, the rate of SVR in patients with a high viral load was the same (43\%) irrespective of whether the cut-off was defined as 400000 or $800000 \mathrm{IU} / \mathrm{mL}$.

The appropriateness of the $400000 \mathrm{IU} / \mathrm{mL}$ cut-off was confirmed by the ROC analysis. The point on the ROC curve that maximizes the vertical distance from the 45degree line is close to $400000 \mathrm{IU} / \mathrm{mL}$ and represents the cut-off with the lowest total error rate $(\mathrm{TPF}+\mathrm{FPF})$ and with the maximal sum of sensitivity (TPF) and specificity (1-FPF) (Fig. 3a). The sensitivity of a cut-off of $400000 \mathrm{IU} / \mathrm{mL}$ was 0.33 , and the specificity was 0.87 . The positive and negative predictive values were 0.70 and 0.57 , respectively.

Genotype 1, persistently 'normal' serum ALT levels Baseline serum HCV RNA level was the only factor that significantly predicted SVR (odd ratio [OR] 0.362, 95\% confidence interval [CI]: $0.160,0.822 ; P=0.0152$ ) in the MLR analysis of data from genotype 1-infected patients with 'normal' ALT levels (Table 2). Other exploratory factors showed the same trends as those for genotype 1-infected patients with elevated ALT levels. 

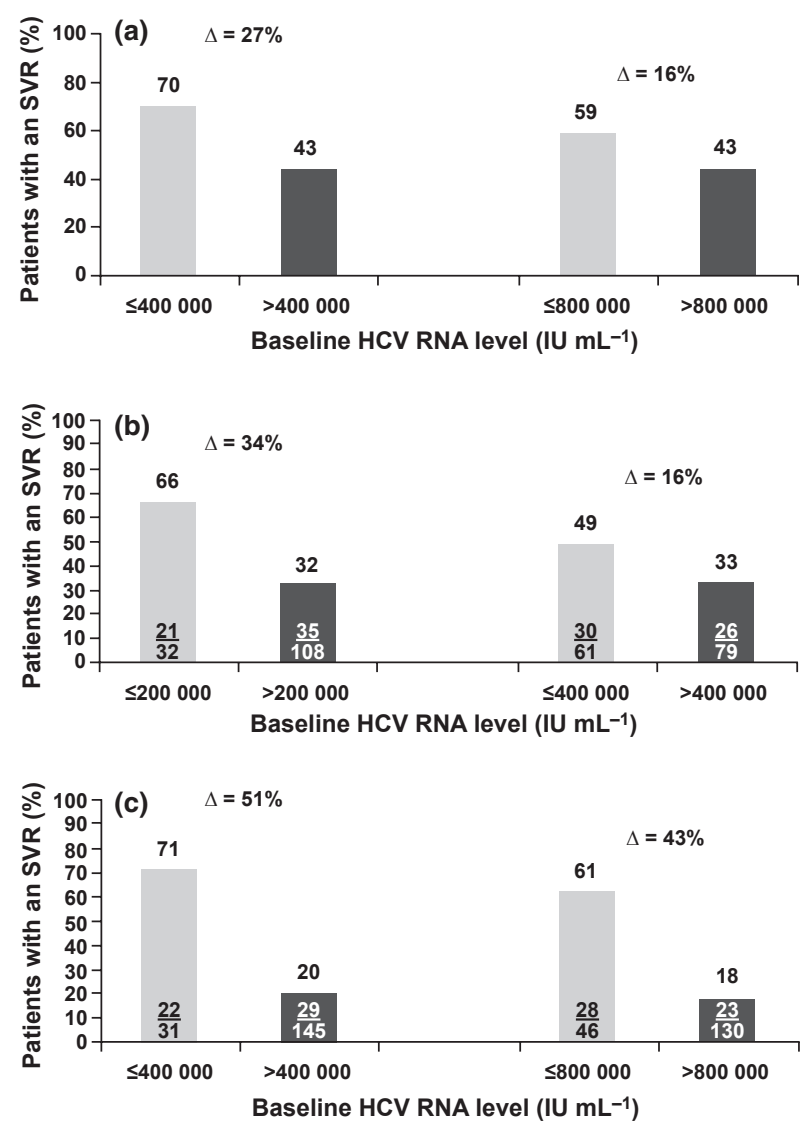

Fig. 2 Difference in sustained virological response (SVR) rates between genotype 1 patients with high and low pretreatment hepatitis C virus (HCV) RNA levels. The impact of different thresholds to define low serum HCV RNA level $(\leq 400000$ and $\leq 800000 \mathrm{IU} / \mathrm{mL}$ ) on the difference $(\Delta)$ in SVR rates between patients with low and high serum HCV RNA levels. (a) HCV mono-infected patients with elevated alanine aminotransferase (ALT) levels; (b) HCV mono-infected patients with persistently 'normal' ALT levels; (c) HIV-HCV co-infected patients.

The general shape of the GAM curve for patients with 'normal' ALT levels (Fig. 1d) is similar to that for patients with elevated ALT levels (Fig. 1a). However, when compared with patients with elevated ALT levels, the decrease in the probability of SVR for each $1-\log _{10}$ drop in HCV RNA level is greater for patients with 'normal' ALT levels, and the probability of SVR is lower for individuals with pretreatment HCV RNA values above $100000 \mathrm{IU} / \mathrm{mL}$.

Among patients with 'normal' ALT levels, the probability of achieving an SVR was 50\% for individuals with a pretreatment HCV RNA level of $\sim 5.25 \quad \log _{10} \mathrm{IU} / \mathrm{mL}$ ( $180000 \mathrm{IU} / \mathrm{mL}$ ) and was $40 \%$ (identical to the overall observed SVR rate) for individuals with a pretreatment HCV RNA level of $5.41 \log _{10} \mathrm{IU} / \mathrm{mL}(\sim 260000 \mathrm{IU} / \mathrm{mL})$.

The point on the ROC curve that maximized the vertical distance from the 45-degree line and therefore minimized the total error rate corresponded to a pretreatment HCV RNA level of $5.21 \log _{10} \mathrm{IU} / \mathrm{mL}(\sim 163000 \mathrm{IU} / \mathrm{mL})$ (Fig. 3d).

The sensitivity (TPF) for a cut-off of $163000 \mathrm{IU} / \mathrm{mL}$ was 0.36 , and the specificity (1-FPF) was 0.93 . The positive predictive value and negative predictive value were 0.77 and 0.68 , respectively.

When a pretreatment HCV RNA level of $163000 \mathrm{IU} / \mathrm{mL}$ was selected as the cut-off to differentiate low from high pretreatment viral load, the difference in SVR rates was $45 \%$ ( $77 \%$ vs $32 \%$ ). The use of higher cut-offs resulted in lower differences in SVR rates: $34 \%$ if the cut-off was set at $200000 \mathrm{IU} / \mathrm{mL}$ (66\% vs 32\%) (Fig. 2b); 16\% if the cut-off was set at $400000 \mathrm{IU} / \mathrm{mL}$ (49\% vs 33\%) (Fig. 2b); and $20 \%$ if the cut-off was set at $800000 \mathrm{IU} / \mathrm{mL}$ (47\% vs $27 \%$ ).

\section{Genotype 2 or 3, elevated serum ALT levels}

An MLR analysis of data from all patients infected with genotype 2 or $3(n=818)$ demonstrated that HCV genotype (OR 0.373 for genotype 3 vs genotype 2, 95\% CI: 0.258 , $0.541 ; P \leq 0.0001)$ was a significant predictor of SVR. Therefore, separate models were constructed for each genotype. The factors predictive of SVR were similar in both analyses, although baseline serum HCV RNA level was a more important predictor of SVR for genotype 3-infected patients and a diagnosis of bridging fibrosis/cirrhosis was a more important predictor of SVR for genotype 2-infected patients.

Significant predictors of lower SVR among genotype 2infected patients included histological diagnosis (OR 0.359 for bridging fibrosis/cirrhosis vs minimal fibrosis, 95\% CI: $0.202,0.635 ; P=0.0004$ ), lower ALT quotient (OR 0.810, 95\% CI: 0.691, 0.949; $P=0.0094)$, higher body weight (OR 0.824 per $10 \mathrm{~kg}$, 95\% CI: 0.714, 0.950; $P=0.0078$ ) and higher pretreatment HCV RNA level (OR 0.688, 95\% CI: 0.483, 0.980; $P=0.038$ ).

Among genotype 3-infected patients, lower SVR was predicted by histological diagnosis (OR 0.539 for bridging fibrosis/cirrhosis, 95\% CI: 0.313, 0.927; $P=0.0256$ ), lower ALT quotient (OR 0.814, 95\% CI: $0.698, \quad 0.948$; $P=0.0083$ ), higher bodyweight (OR 0.774 per $10 \mathrm{~kg}, 95 \%$ CI: $0.670,0.893 ; P=0.0005)$ and higher pretreatment HCV RNA level (OR 0.590, 95\% CI: 0.435, 0.801; $P=0.0007)$.

The GAM analysis for genotype 2-infected patients showed that SVR decreased with increasing HCV RNA level up to $\sim 100000 \mathrm{IU} / \mathrm{mL}$, remained fairly constant ( 80\%) between $100000 \mathrm{IU} / \mathrm{mL}$ and $1000000 \mathrm{IU} / \mathrm{mL}$ and decreased thereafter (Fig. 1b). Among patients with HCV genotype 3 infection, SVR declined at a fairly constant rate over the range of values encountered (Fig. 1c) and remained $>60 \%$ for all patients, including those with very high HCV RNA levels.

In contrast to patients infected with HCV genotype 1, ROC curves for patients infected with HCV genotypes 2 or 3 
(a)

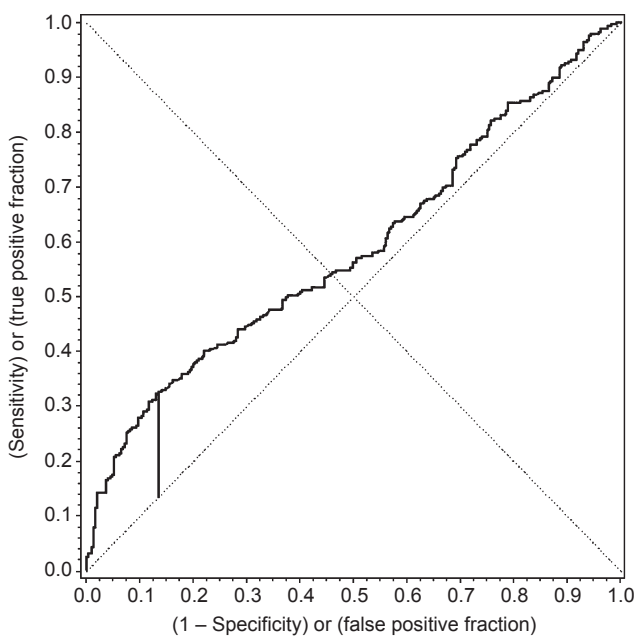

(b)

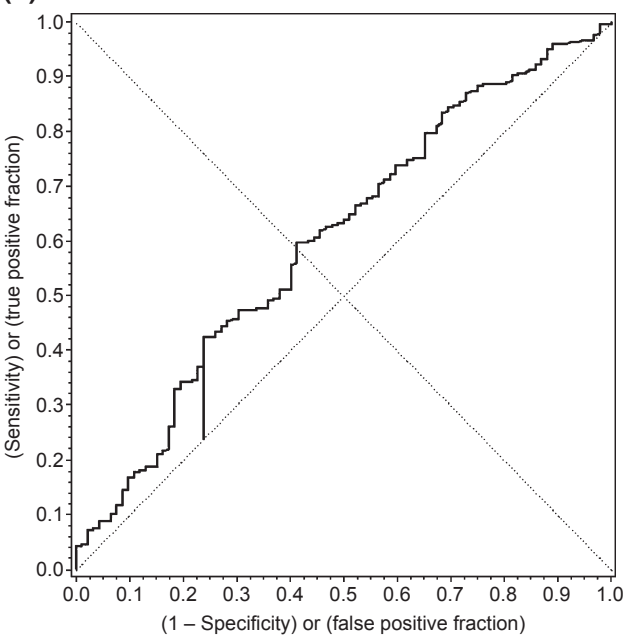

(c)

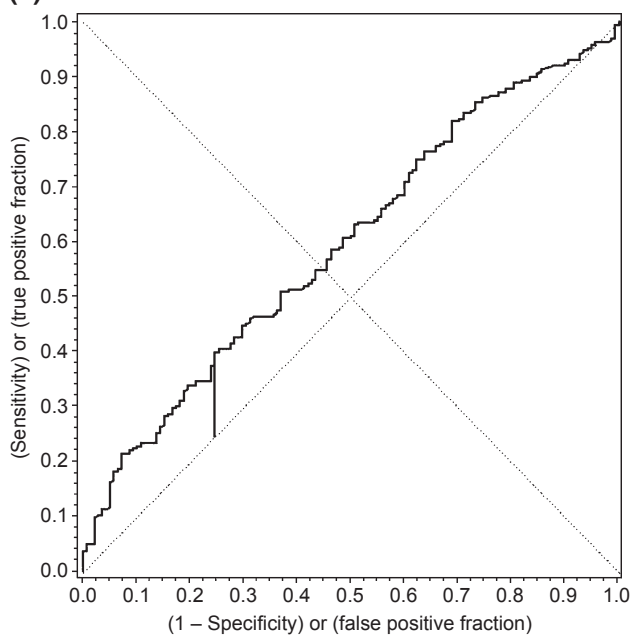

(d)

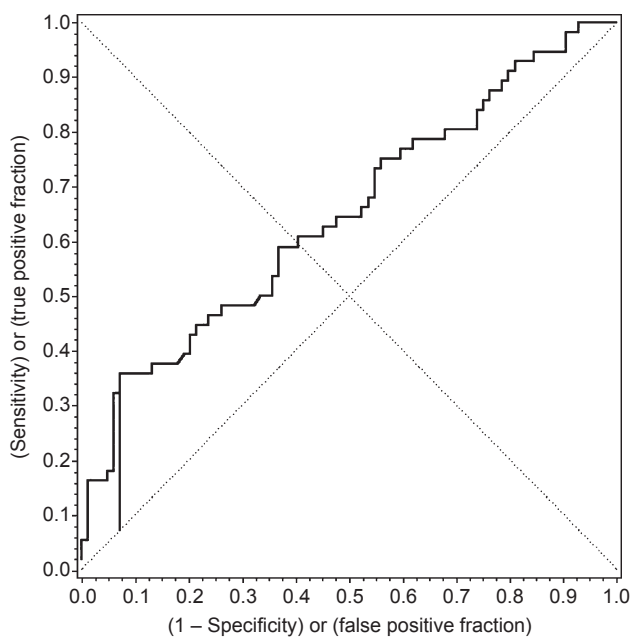

(e)

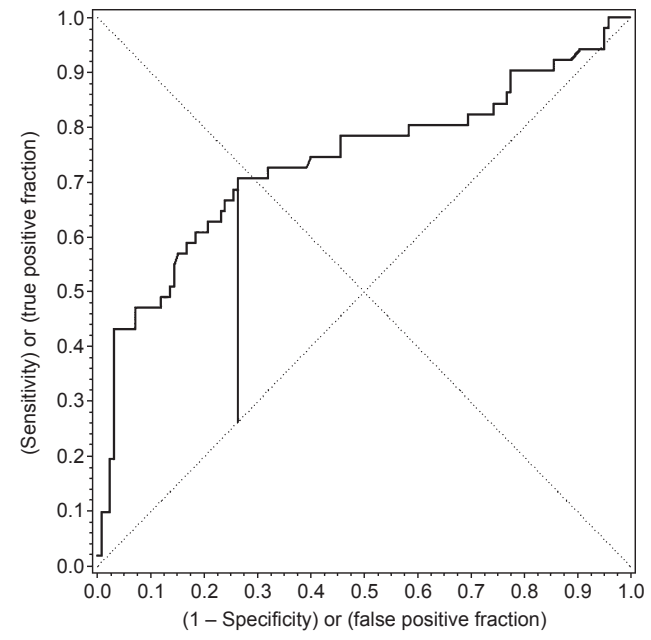


revealed no obvious cut-off to discriminate between responders and nonresponders (Figs. 3b,c). Moreover, the differences in SVR rate between patients with low and high pretreatment HCV RNA levels when cut-offs of 400000 and $800000 \mathrm{IU} / \mathrm{mL}$ were selected were $9 \%$ (84\% vs $75 \%)$ and $10 \%$ ( $84 \%$ vs $74 \%$ ), respectively, for genotype 2-infected patients and $15 \%$ (79\% vs $64 \%$ ) and $13 \%$ (76\% vs $63 \%)$, respectively, for genotype 3 -infected patients.

\section{Genotype 1-infected patients with HIV-HCV co-infection}

Baseline serum HCV RNA level and ALT ratio were the only significant factors that predicted SVR in the MLR analysis of data from HIV-HCV co-infected patients (Table 2). All other exploratory factors showed the same predictive trends as observed for genotype 1-infected patients with elevated ALT levels.

The general shape of the GAM curve was similar to that from patients with HCV genotype 1 mono-infection (Fig. 1e). The steepest slope of the curve and the point at which the curve crosses the 0.5 line coincides with an HCV RNA level of $\sim 5.6 \log _{10} \mathrm{IU} / \mathrm{mL}(\sim 400000 \mathrm{IU} / \mathrm{mL})$.

The point on the ROC curve that minimized the total error rate corresponded to a pretreatment HCV RNA level of 6.32 $\log _{10} \mathrm{IU} / \mathrm{mL}(\sim 2100000 \mathrm{IU} / \mathrm{mL}$ ) (Fig. 3e). The sensitivity (TPF) for a cut-off of $2100000 \mathrm{IU} / \mathrm{mL}$ was 0.71 , while the specificity (1-FPF) was 0.74 . The positive and negative predictive values were 0.52 and 0.86 , respectively. When, instead of the minimal total error rate of a cut-off, the simple difference in SVR rates was used to differentiate between patients with low and high pretreatment HCV RNA; the value of $2100000 \mathrm{IU} / \mathrm{mL}$ was not optimal. The difference in SVR rate was 38\% (52\% vs $14 \%$, respectively) for this cutoff, while for a cut-off of $400000 \mathrm{IU} / \mathrm{mL}$, the difference in SVR rate was $51 \%$ ( $71 \%$ vs $20 \%$ ) and $43 \%$ (61 vs 18\%) for the cut-off of $800000 \mathrm{IU} / \mathrm{mL}$ (Fig. 2c).

\section{DISCUSSION}

This analysis confirms that SVR decreases with increasing viral load in patients infected with HCV genotypes 1, 2 or 3. The analysis extends our understanding for HCV genotype 1 patients by showing that the optimal cut-off that differentiates between high and low viral load is lower than the traditional threshold. The analysis also shows that for genotype 2 or 3 infection, the concept of high and low viral load is less relevant, and no defined cut-off can clearly differentiate high from low baseline viral load.

The difference in SVR rate between mono-infected patients with low and high baseline serum HCV RNA levels was considerably greater when the threshold was set at $400000 \mathrm{IU} / \mathrm{mL}(27 \%)$ than when it was set at $800000 \mathrm{IU} /$ $\mathrm{mL}(16 \%)$. This is noteworthy because a definition of $800000 \mathrm{IU} / \mathrm{mL}$ for high HCV RNA level has historically been used to define high serum HCV RNA levels in numer- ous guidelines for the treatment of chronic hepatitis $\mathrm{C}$ $[4,23,24]$ and is reflected in the current licences for pegylated interferons.

Our findings are consistent with those of two other analyses in patients infected with HCV genotype 1, both of which identified a critical threshold of $400000 \mathrm{IU} / \mathrm{mL}$ using the ROC curve method of analysis [25,26]. In the first of these studies, the rate of SVR was $70 \%$ among patients with pretreatment serum HCV RNA levels $\leq 400000 \mathrm{IU} / \mathrm{mL}$ compared with $46 \%$ among those with pretreatment serum HCV RNA levels $>400000 \mathrm{IU} / \mathrm{mL}$ (difference 24\%; $P<0.0001$ ). By contrast, SVR was $58 \%$ among patients with pretreatment serum HCV RNA levels $\leq 800000 \mathrm{IU} / \mathrm{mL}$ compared with $45 \%$ among those with pretreatment serum HCV RNA levels $>800000 \mathrm{IU} / \mathrm{mL}$ (difference 13\%; $P=0.007$ ) [25].

The results of the analysis in HCV genotype 1-infected patients with elevated serum ALT levels show that a pretreatment serum HCV RNA level of $5.6 \log _{10} \mathrm{IU} / \mathrm{mL}$ $(\sim 400000 \mathrm{IU} / \mathrm{mL})$ is the threshold that offers an improved discrimination between a high and low probability of achieving an SVR. The definition applies to both HCV monoinfected and HIV-HCV co-infected patients. By contrast, a lower threshold $(\sim 200000 \mathrm{IU} / \mathrm{mL})$ appears to be more appropriate for HCV genotype 1 mono-infected patients with persistently 'normal' serum ALT levels. In contrast to the findings in patients infected with HCV genotype 1, the analyses of data from patients infected with HCV genotypes 2 or 3 did not identify a fixed threshold that can be used to differentiate patients with a high or a low probability of achieving an SVR.

Taken together, the results of our analysis and the studies of abbreviated therapy suggest that the pretreatment $\mathrm{HCV}$ RNA level should be an important component of responseguided therapy algorithms primarily for genotype 1-infected patients. Among patients with an RVR, those with pretreatment HCV RNA levels $\leq 400000 \mathrm{IU} / \mathrm{mL}$ are the best candidates for abbreviated therapy; and those with higher HCV RNA levels retain a high likelihood of achieving an SVR, but they would be better managed with the full 48-week treatment duration.

Data from a trial conducted exclusively in patients infected with HCV genotypes 2 or 3 show that abbreviated therapy is less successful for patients with high pretreatment HCV RNA levels [19]. Among patients treated for 24 weeks with peginterferon alfa-2a (40 kD) plus ribavirin, the difference in the rate of SVR between those with a pretreatment serum HCV RNA level of $\leq 400000 \mathrm{IU} / \mathrm{mL}$ and those with $>400000 \mathrm{IU} / \mathrm{mL}$ was $13 \%$ ( $81 \%$ vs $68 \%$, respectively), and among patients treated for 16 weeks, the difference in SVR rate was $25 \%(82 \%$ vs $57 \%)$. On this basis, the authors concluded that abbreviated therapy should only be contemplated for HCV genotype 2- or 3-infected patients with a pretreatment HCV RNA level $\leq 400000 \mathrm{IU} / \mathrm{mL}$ [27].

Although in the present analysis we have shown that a threshold of $400000 \mathrm{IU} / \mathrm{mL}$ may be more discriminating 
than a threshold of $800000 \mathrm{IU} / \mathrm{mL}$, it remains to be determined what, if any, threshold may be optimal among patients receiving peginterferon plus ribavirin in combination with new therapies, such as HCV protease inhibitors.

Recently, it has been shown that a genetic variation associated with the IL28B gene that confers an improved SVR to patients with genotype 1 treatment-naive HCV infection [28]. This genetic polymorphism is associated with an approximately twofold change in response to treatment and is more predictive than viral load and fibrosis stage [29]. As such, we will likely be testing for the IL28B allele prior to initiation of treatment as soon as assays are commercially available. This may diminish, but will certainly not eliminate, the importance of pretreatment viral load in genotype 1 patients.

In conclusion, among patients with HCV genotype 1 infection and elevated serum ALT levels, a pretreatment serum HCV RNA level of $400000 \mathrm{IU} / \mathrm{mL}$ is an optimized threshold for differentiating between patients with a high and low probability of achieving an SVR when treated for 48 weeks with peginterferon alfa- $2 \mathrm{a}(40 \mathrm{kD})$ plus ribavirin. The threshold can be applied in the setting of HCV monoinfection and HIV-HCV co-infection. In the era of responseguided therapy, this threshold may be useful for identifying the HCV mono-infected patients who are most likely to respond to an abbreviated treatment regimen.

\section{ACKNOWLEDGEMENTS AND DISCLOSURES}

SZ has served as a speaker, a consultant, or an advisory board member for Roche/Genentech, Merck, and BristolMyers Squibb. MRT has served as a consultant for Roche, Abbott Labs, Anadys, Pharmasset, Akros, Genentech, Bristol-Myers Squibb, Novartis, and Merck, and has received research funding from Vertex, Anadys, Roche, GlaxoSmithKline, Novartis, Bristol-Myers Squibb, Idera, Pharmasset, Sanofi-Aventis, Merck, Abbott, Pfizer, Human Genome Sciences, Gilead Sciences, Johnson \& Johnson, Zymogenetics, Akros, Pfizer, Merck, Scynexis, Santaris, Mochida, Boehringer-Ingelheim, Inhibitex, Idenix, and Siemens. KRR has served as an advisory board member for
Roche, Genentech, Merck, Tibotec, Gilead Sciences, and Vertex, and has received research funding from BristolMyers Squibb, Roche, Merck, Tibotec, Gilead Sciences, and Vertex. PM has served as a speaker, a consultant, or an advisory board member for Roche, Schering-Plough, Gilead Sciences, Bristol-Myers Squibb, Vertex, Novartis, Pharmasset, Tibotec, Merck Sharp \& Dohme, Boehringer-Ingelheim, Abbott, and Pfizer, and has received research funding from Roche, Schering-Plough, Gilead Sciences, and Echosens. PP has served as a speaker, a consultant, or an advisory board member for Roche, Vertex, and Bristol-Myers Squibb, and has received research funding from Roche, Vertex, and Bristol-Myers Squibb. MR has served as an advisory board member for Merck Sharp \& Dohme, Roche, and BristolMyers Squibb. DB has received research funding from Roche. MLS has served as a speaker, a consultant, or an advisory board member for Abbott, Anadys Pharmaceuticals, Bayer, Biolex Therapeutics, Bristol-Myers Squibb, Celera Diagnostics, Conatus Pharmaceuticals, Echosens, Exalenz Bioscience, Gilead Sciences, Human Genome Sciences, Merck \& Co., Schering-Plough, Pfizer, Roche, Romark Laboratories, LC, Salix Pharmaceuticals, Valeant Pharmaceuticals, Vertex Pharmaceuticals, and Zymogenetics, and has received research funding from Biolex Therapeutics, Celera Diagnostics, Conatus Pharmaceuticals, Exalenz Bioscience, Gilead Sciences, GlaxoSmithKline, GlobeImmune, Human Genome Sciences, Idenix, Johnson \& Johnson/ Tibotec, Pharmasset, Schering, Roche, Romark Laboratories, LC, Valeant Pharmaceuticals, Vertex Pharmaceuticals, Wyeth, and Zymogenetics. AL is an employee of F. Hoffmann-La Roche Ltd. FT is an employee of F. Hoffmann-La Roche Ltd. SH has served as a speaker, a consultant or an advisory board member for Roche, Gilead Sciences, and Novartis, and has received research funding from Roche and Gilead Sciences. MLS owns stocks and shares in Exalenz Bioscience Ltd.

This study was funded in full by F. Hoffmann-La Roche Ltd. Writing support was provided by Blair Jarvis MSc of Health Interactions and funded by F. Hoffmann-La Roche Ltd.

\section{REFERENCES}

1 Dienstag JL, McHutchison JG. American Gastroenterological Association technical review on the management of hepatitis C. Gastroenterology 2006; 130: 231-264.

2 Ghany MG, Strader DB, Thomas DL, Seeff LB. Diagnosis, management, and treatment of hepatitis $\mathrm{C}$ : an update. Hepatology 2009; 49: 13351374 .

3 Zeuzem S. Heterogeneous virologic response rates to interferon-based therapy in patients with chronic hepatitis C: who responds less well? Ann Intern Med 2004; 140: 370-381.

4 EASL consensus panel. EASL International Consensus Conference on Hepatitis C. Paris, 26-28 February 1999, Consensus Statement. European Association for the Study of the Liver. J Hepatol 1999; 30: 956961.

5 McHutchison JG, Gordon SC, Schiff ER et al. Interferon alfa- $2 \mathrm{~b}$ alone or in combination with ribavirin as initial treatment for chronic hepatitis C. Hepatitis Interventional Therapy Group. N Engl J Med 1998; 339: 1485-1492.

6 Poynard T, Marcellin P, Lee SS et al. Randomised trial of interferon alpha2b plus ribavirin for 48 weeks or for 24 weeks versus interferon alpha $2 \mathrm{~b}$ plus placebo for 48 weeks for treatment of chronic infection with hepatitis $C$ virus. International 
Hepatitis Interventional Therapy Group (IHIT). Lancet 1998; 352: 1426-1432.

7 Heathcote EJ, Shiffman ML, Cooksley WG et al. Peginterferon alfa-2a in patients with chronic hepatitis $\mathrm{C}$ and cirrhosis. N Engl J Med 2000; 343: 1673-1680.

8 Pockros PJ, Carithers R, Desmond P et al. Efficacy and safety of two-dose regimens of peginterferon alpha- $2 \mathrm{a}$ compared with interferon alpha-2a in chronic hepatitis C: a multicenter, randomized controlled trial. Am J Gastroenterol 2004; 99: 12981305.

9 Zeuzem S, Feinman SV, Rasenack J et al. Peginterferon alfa-2a in patients with chronic hepatitis C. $N$ Engl J Med 2000; 343: 1666-1672.

10 Fried MW, Shiffman ML, Reddy KR et al. Peginterferon alfa-2a plus ribavirin for chronic hepatitis $\mathrm{C}$ virus infection. N Engl J Med 2002; 347: 975-982.

11 Hadziyannis SJ, Sette H Jr, Morgan TR et al. Peginterferon-alpha2a and ribavirin combination therapy in chronic hepatitis $\mathrm{C}$ : a randomized study of treatment duration and ribavirin dose. Ann Intern Med 2004; 140: 346-355.

12 Manns MP, McHutchison JG, Gordon $\mathrm{SC}$ et al. Peginterferon alfa-2b plus ribavirin compared with interferon alfa- $2 b$ plus ribavirin for initial treatment of chronic hepatitis C: a randomised trial. Lancet 2001; 358: 958-965.

13 Scott JD, Gretch DR. Molecular diagnostics of hepatitis $C$ virus infection: a systematic review. JAMA 2007; 297: 724-732.

14 Pegasys. Summary of product characteristics. Available at: http://www. ema. europa.eu/docs/en_GB/document_
library/EPAR_-_Summary_for_the_ public/human/000395/WC5000391 96.pdf (accessed 20 September 2010).

15 Soriano V, Puoti M, Sulkowski M et al. Care of patients coinfected with HIV and hepatitis C virus: 2007 updated recommendations from the HCV-HIV International Panel. AIDS 2007; 21: 1073-1089.

16 Dalgard O, Bjøro K, Ring-Larsen H et al. Pegylated interferon alfa and ribavirin for 14 versus 24 weeks in patients with hepatitis $\mathrm{C}$ virus genotype 2 or 3 and rapid virological response. Hepatology 2008; 47: 35-42.

17 Jensen DM, Morgan TR, Marcellin P et al. Early identification of $\mathrm{HCV}$ genotype 1 patients responding to 24 weeks peginterferon alpha-2a (40 kd)/ribavirin therapy. Hepatology 2006; 43: 954-960.

18 Mangia A, Minerva N, Bacca D et al. Individualized treatment duration for hepatitis $\mathrm{C}$ genotype 1 patients: a randomized controlled trial. Hepatology 2008; 47: 43-50.

19 Shiffman ML, Suter F, Bacon BR et al. Peginterferon alfa-2a and ribavirin for 16 or 24 weeks in $\mathrm{HCV}$ genotype 2 or 3. N Engl J Med 2007; 357: 124-134.

20 Zeuzem S, Diago M, Gane E et al. Peginterferon alfa-2a (40 kilodaltons) and ribavirin in patients with chronic hepatitis $\mathrm{C}$ and normal aminotransferase levels. Gastroenterology 2004; 127: 1724-1732.

21 Torriani FJ, Rodriguez-Torres M, Rockstroh JK et al. Peginterferon alfa-2a plus ribavirin for chronic hepatitis $\mathrm{C}$ virus infection in HIVinfected patients. N Engl J Med 2004; 351: 438-450.

22 Hastie T, Tibshirani R. Generalized Additive Models. London: Chapman \& Hall, 1990.
23 Dienstag JL, McHutchison JG American Gastroenterological Association medical position statement on the management of hepatitis $\mathrm{C}$. Gastroenterology 2006; 130: 225230.

24 National Institutes of Health. National Institutes of Health Consensus Development Conference Statement: Management of hepatitis C: 2002 - June 10-12, 2002. Hераtology 2002; 36(s1): S3-S20.

25 Berg T, von Wagner M, Hinrichsen H et al. Definition of a pre-treatment viral load cut-off for an optimized prediction of treatment outcome in patients with genotype 1 infection receiving either 48 or 72 weeks of peginterferon alfa-2a plus ribavirin. Hepatology 2006; 44(s1): 321A.

26 Zehnter E, Mauss S, John C et al. Better prediction of SVR in patients with HCV genotype 1 (G1) with peginterferon alfa-2a (PEGASYS) plus ribavirin: improving differentiation between low (LVL) and high baseline viral load (HVL). Hepatology 2006; 44(s1): 328A.

27 Shiffman ML, Di Bisceglie AM, Lindsay KL et al. Peginterferon alfa-2a and ribavirin in patients with chronic hepatitis $\mathrm{C}$ who have failed prior treatment. Gastroenterology 2004; 126: 1015-1023.

28 Ge D, Fellay J, Thompson AJ et al. Genetic variation in IL28B predicts hepatitis C treatment-induced viral clearance. Nature 2009; 461: 399 401.

29 Alberti A, Clumeck N, Collins S et al. Short statement of the first European consensus conference on the treatment of chronic hepatitis B and C in HIV co-infected patients. J Hepatol 2005; 42: 615-624. 